\title{
Epidemiology of sorghum anthracnose (Colletotrichum sublineolum) and leaf blight (Exserohilum turcicum) in Kenya
}

\author{
H. K. Ngugi ${ }^{a *} \dagger$, A. M. Julian ${ }^{b}$, S. B. King ${ }^{a} \ddagger$ and B. J. Peacocke

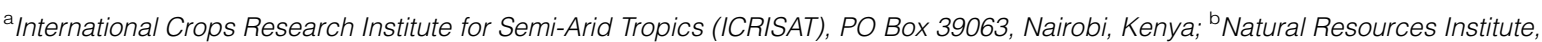 \\ Central Avenue, Chatham Maritime, Kent ME4 4TB, UK; and ${ }^{\mathrm{C}}$ Department of Agriculture, University of Reading, Earley Gate, \\ Reading RG6 2AT, UK
}

\begin{abstract}
A 3-year study on the epidemiology of sorghum anthracnose (Colletotrichum sublineolum) and leaf blight (Exserohilum turcicum) was conducted at Alupe in western Kenya from 1994 to 1996. A nonlinear logistic model was used to summarize 72 anthracnose and 108 leaf blight disease progress curves from different planting dates and cultivars. Effects of planting date and cultivar on disease development were compared based on estimates of the rate $(\beta)$, the absolute rate $(\theta)$, inflection point $(\mu)$ and upper asymptote $(\gamma)$, disease severity at milk stage $\left(v_{95}\right)$, and time taken to reach a disease severity of $2 \%\left(t_{2}\right.$, an estimate of time when disease is first observed). Leaf blight epidemics always started earlier than those of anthracnose, but exhibited lower disease severity at crop maturity. Effects of planting date and cultivar on $\beta$ varied between years. Delaying planting reduced time to disease onset (i.e. $\mu$ and $t_{2}$ ) and increased absolute rate of progress $\theta$, resulting in maximum severity at crop 'milk stage' and maturity $\left(v_{95}\right.$ and $\gamma$, respectively). Resistant cultivars had highest $\mu$ and $t_{2}$ but lowest $\theta, v_{95}$ and $\gamma$ values for both diseases. Delaying planting affected anthracnose progress more on the resistant cultivars, in contrast with leaf blight for which progress on susceptible cultivars was more affected. The implications of these findings for disease management are discussed, and recommendations made to improve disease screening methodologies.
\end{abstract}

Keywords: anthracnose, epidemiology, disease progress curves, parameter estimates, planting date, sorghum cultivars

\section{Introduction}

Although sorghum (Sorghum bicolor) is the third most important cereal in Kenya (Mukuru, 1993; FAO, 1997), average yields are below 1 tonne per hectare (FAO, 1997), compared with attainable yields in excess of 5 tonnes (ICRISAT 1992-96, unpublished data). Virtually all the sorghum is produced by subsistence farmers on small land holdings, who have limited access to inputs such as fertilizers and pesticides. Production occurs in two distinct agro-ecozones (Rutto, 1982), the dry hot lowlands, characterized by low erratic rainfall and comprising much of the Eastern Province and southern part of Nyanza Province, and the wet humid to subhumid zones in western Kenya. The fungal diseases

*To whom correspondence should be addressed.

$\dagger$ Present address: Natural Resources Institute, Central Avenue, Chatham Maritime, Kent ME4 4TB, UK.

$\ddagger$ Present address: 1448 Hampton Circle, Goshen, IN 46526, USA.

Accepted 9 September 1999. anthracnose (caused by Colletotrichum sublineolum (Sutton, 1980) and leaf blight (caused by Exserohilum turcicum) are considered important constraints to production, particularly in the wetter areas (Hulluka \& Esele, 1992; Mukuru, 1993; King \& Mukuru, 1994). Quantitative estimates of yield losses from these diseases in Kenya do not exist, but losses in excess of $50 \%$ have been reported elsewhere on susceptible sorghum cultivars for anthracnose (Harris et al., 1964; Powell et al., 1977; Thomas et al., 1996) and for leaf blight (Dogget, 1988).

Both C. sublineolum and E. turcicum can survive from season to season as mycelia, sclerotia or chlamydospores on infected crop debris or in the soil (Tarr, 1962; Levy, 1984; Casela \& Frederiksen, 1993). Alternative hosts and volunteer crops may also provide sources of primary inoculum, and seed transmission has been reported for both C. sublineolum (Basu Chaudhary \& Mathur, 1979; Cardwell, 1989) and E. turcicum (Nobel \& Richardson, 1968). Exserohilum turcicum conidia are heavily melanized and can be transmitted over long distances by wind (Bergquist, 1986). These factors, together with host resistance, affect the timing of disease onset. 
Both anthracnose and leaf blight are polycyclic diseases. Disease epidemics are favoured by high rainfall and relative humidity, moderate temperatures, and the presence of large amounts of inoculum (Berger, 1970; Benedict, 1979; Frederiksen, 1986; Hennessy et al., 1990). However, severe epidemics can occur, even in suboptimal conditions, where highly pathogenic strains infect susceptible host cultivars (Levy, 1991; Pande et al., 1991). Within a host crop, secondary spread of C. sublineolum is primarily through rain-splashed spores. It has also been speculated that the conidial mucilage may act as a protectant, allowing windborne dispersal of dry conidial masses (Nicholson \& Moraes, 1980). Exserohilum turcicum spores follow a diurnal pattern of liberation, with maximum release during the morning as the sun dries out the leaf surface. Thereafter, secondary dissemination can be by wind or water (Meredith, 1965; Bergquist, 1986).

Previous studies on the epidemiology of these diseases have indicated that leaf blight is often more severe on younger plants (Tuleen \& Frederiksen, 1977; Julian et al., 1994), while severe anthracnose is associated with mature plants (Jamil \& Nicholson, 1987; Ashok-Mishra et al., 1992). However, there is little definitive information on the mechanisms underlying these observations. Information on how these diseases develop in the field is needed in order to standardize screening procedures and to relate yield losses to disease severity. One approach to investigating the different factors influencing temporal disease progress is sequentially to plant cultivars with varying levels of disease expression. This provides information on the host-pathogen interaction under varying environmental conditions. Such information can be quantified using mathematical models to summarize disease progress (Rouse, 1985; Madden, 1986; Madden \& Campbell, 1990). Disease progress curves describing the development of anthracnose or leaf blight relative to sorghum growth have been constructed in a number of studies (Ferreira \& Warren, 1982; Julian \& de Milliano, 1992; Casela et al., 1993; Thomas et al., 1996). However, no attempt has been made to analyse such curves mathematically in order to determine the parameters that best describe disease progress. The aim of the present study was to construct disease progress curves to describe the temporal development of anthracnose and leaf blight severity on sorghum, and to analyse and compare the effects of host age, delayed planting and season on disease progress.

\section{Materials and methods}

\section{Field experiments}

Experiments were carried out on fields allocated to ICRISAT at the Alupe Research Sub-centre (ARSC) of the Kenya Agricultural Research Institute (KARI) in western Kenya. Experiments were conducted in the 1994 short-rains season and repeated in the 1995 and 1996 long-rains seasons. Alupe is $1189 \mathrm{~m}$ above sea level at a latitude of $0^{\circ} 29^{\prime} \mathrm{N}$ and longitude $34^{\circ} 08^{\prime} \mathrm{E}$, with a humid equatorial climate (Jaetzold \& Schmidt, 1982). The fields used had been sown with cowpea the previous season, following an established rotation programme. Three improved sorghum cultivars were used: KARI Mtama 1 (a released cultivar susceptible to both anthracnose and leaf blight in Kenya); IS 18758 (an entry in the International Sorghum Anthracnose Virulence Nursery that had previously shown moderate resistance to anthracnose at Alupe); and IS 8193 (an ICRISAT line with resistance to both diseases at the on-farm testing stage in Kenya).

These cultivars were selected on the basis of their different reactions to both anthracnose and leaf blight, and for their uniformity in time to maturity. Uniform maturity allowed a direct comparison of disease progress curves of the three cultivars, without the need to allow for different developmental stages. Three planting dates, at 10-day intervals, were used each season, starting on 25 August in 1994, 9 March in 1995 and 21 March in 1996. When rainfall failed at planting, the soil was irrigated to improve emergence and to maintain a 10 -day interval between planting dates. The design followed was a split-plot arrangement, replicated four times, with planting dates assigned as main plots and cultivars as subplots. Each subplot consisted of four $4^{\circ} \mathrm{m}$ rows, $60 \mathrm{~cm}$ apart. Within rows, plants were thinned to a spacing of $15-20 \mathrm{~cm}$. To minimize interplot interference (Vanderplank, 1963) the experiment was surrounded by four rows of maize, and only the two middle rows of each subplot were assessed for disease development.

All experiments relied entirely on natural inoculum for disease development. Crop developmental stages were identified using a modification of the scale described by Frederiksen (1986). Plants were assessed at 5- to 8-day intervals from booting stage in 1994 and 1995 and from stem elongation stage in 1996, until crop maturity in all treatments. Estimates of disease severity were obtained through nondestructive systematic sampling of 10 plants from the middle two rows of each subplot. Each plant sampled was visually scored for percentage leaf area affected by each disease with reference to standard area diagrams adapted from Saari \& Prescot (1975). Consistency in scoring was maintained by using the same assessor in each season. Prior to disease evaluation, the assessor practised scoring using DISTRAIN (Tomerlin \& Howell, 1988) computer simulations of disease severity. Experimental plots were assessed for disease six, ten and eight times in 1994, 1995 and 1996, respectively.

\section{Statistical analysis}

For each assessment date, data from each subplot treatment were averaged to give a single severity value for each disease, based on a mean of the 10 plants evaluated. In order to compare treatment effects and to obtain information on disease dynamics, disease 
progress curves were constructed by plotting percentage disease severity against time in days after crop emergence. For each season, separate curves were constructed for each disease in every subplot. In preliminary analyses, correlation between the severities of anthracnose and leaf blight in the same plot was assessed through covariance and joint (bivariate) analyses (Mead et al., 1993). In the absence of a significant correlation between the diseases, nonlinear forms of the logistic and Gompertz models were tested for goodness of fit to the disease progress data, all of which had generally sigmoid curves. The criteria for model evaluation were visual examination of plots of observed values compared with fitted lines, and the coefficient of determination $\left(R^{2}\right)$, which is the measure of the proportion of variation accounted for by the model (Campbell \& Madden, 1990).

Although both the logistic and Gompertz models were judged appropriate for describing the data, the logistic regressions accounted for marginally more variation, as indicated by higher $R^{2}$ values, in a majority of cases. Fitting the Gompertz model also resulted in more variation between treatments in $R^{2}$ values and in underestimation of $\gamma$ for anthracnose disease progress curves in 1995. Based on these preliminary results, the three-parameter logistic model was retained for all further comparative studies:

$$
Y_{t}=\gamma / 1+\exp [-\beta(t-\mu)]+\epsilon_{t}
$$

As one of the aims of this study was to describe disease progress curves relative to host developmental stages, three derived parameters were estimated from the model:

$1 v_{95}=\gamma /\{1+\exp [-\beta(95-\mu)]\}$, which is an estimate of disease severity 95 days after emergence. A period of 95 days was selected for these particular cultivars because it coincides with the end of grain milk stage, approximately 3 weeks after $50 \%$ flowering.

$2 t_{2}=\{-\log [(\gamma / 2)-1] / \beta\}+\mu$, which is the time taken for disease severity to reach $2 \%$. This parameter provided an estimate of the time at which disease could be first observed.

3 The absolute rate parameter $\theta(=\beta \times \gamma)$ was estimated in order to facilitate the comparison of disease progress curves having different upper asymptotes.

Models were fitted by maximum-likelihood method through iterative nonlinear searching using GENSTAT 5, Release 3.2 (1993), Fitcurve directive.

Treatment comparisons were based on estimated parameters treated as random variables and compared by ANOVA (Madden, 1986). Univariate split-plot ANOVA was used on each parameter for each year, and where results were judged to be significant $(P<0 \cdot 05)$ standard errors of difference (SED) were calculated for comparison of the means. Normality tests revealed that, with the exception of $v_{95}$ and $t_{2}$, distributions of parameters were highly skewed. Values of $\beta, \mu, \gamma$ and $\theta$ were therefore log-transformed before analysis. Means have been presented after back-transformation. Tests of correlation between various curve parameters were not significant, and it was therefore concluded that multivariate analysis of variance (MANOVA) would add little to the univariate analysis.

\section{Results}

\section{Disease progress curves}

A total of 72 anthracnose and 108 leaf blight disease progress curves were analysed over the three seasons of study. Anthracnose failed to develop in the 1996 experiment despite severe epidemics developing in breeders' nurseries less than $100 \mathrm{~m}$ away from the test plots. As a result, comparisons between progress curves for the two diseases are limited to the 1994 and 1995 data sets. In each year, there were three anthracnose disease progress curves to which the logistic equation could not be fitted because the convergence criteria specified for the algorithm used for parameter estimation were not met. These data were excluded from further analysis. The logistic model provided an excellent fit for the disease progress curve data. Fitted curves (Figs 1 and 2) closely resembled plots of the actual data. The $R^{2}$ values for all converging regressions for individual subplot data were above 0.90 , and in most cases above $0 \cdot 95$. The $R^{2}$ values presented (Figs 1 and 2 ) are those obtained when the model was fitted to the data from four replicates.

The disease progress curves for anthracnose showed a pronounced lag phase followed by a sharp rise in the logistic phase, which coincided with the period after crop flowering, before a short terminal phase (Fig. 1). In contrast, the disease progress curves for leaf blight (Fig. 2) initially rose steeply in the period after crop stem elongation, before a sudden flattening corresponding with crop flowering. This was followed by an extended terminal phase after anthesis. A visual inspection of disease progress curves revealed that, for each treatment, anthracnose developed later than leaf blight relative to the time of crop emergence. Anthracnose disease progress curves also reached higher severity levels than those for leaf blight. This visual observation was consistent with comparisons based on parameter estimates $\left(\mu, t_{2}\right.$ and $\left.\gamma\right)$ derived from the fitted curves for both diseases. Thus in both 1994 and 1995, mean estimates of $\mu, t_{2}$ and $\gamma$ for leaf blight (Tables 3 and 4) were lower than those for anthracnose (Tables 1 and 2) in almost all treatments. One exception was planting date 3 of the resistant cultivar IS 8193, which developed more severe leaf blight than anthracnose in the 1994 experiment.

\section{Relationship between leaf blight and anthracnose}

For all assessment dates, covariance analyses of severity data indicated nonsignificant correlation between 

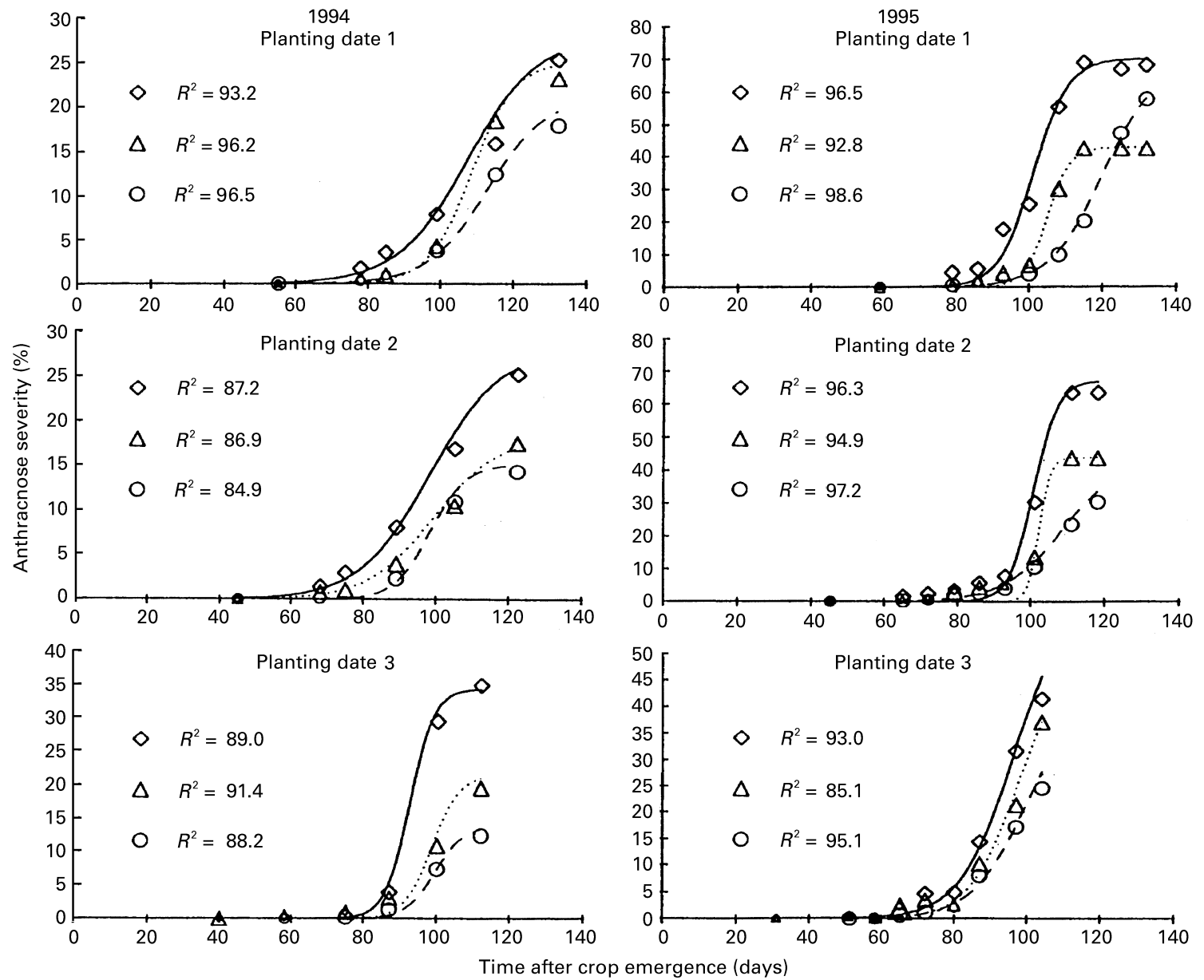

Figure 1 Colletotrichum sublineolum disease progress on three sorghum cultivars planted at three dates at 10-day intervals from 25 August during the 1994 short-rain season, and from 9 March during the 1995 long rains at Alupe: $\diamond$ KARI Mtama 1, $\triangle$ IS 18758, O IS 8193. Points represent means of four replicates, smooth lines are the fitted curves, $R^{2}$ values indicate the percentage variance accounted for by the logistic regression.

anthracnose and leaf blight diseases occurring in the same plot. In 'joint analyses' (Mead et al., 1993), more of the variation was accounted for by differences between treatments (planting date and cultivar) than by the relationship between the two diseases. When the treatment effects were taken into account, correlation coefficients between anthracnose and leaf blight were between -0.353 and -0.113 in 1994 , and between -0.027 and 0.389 in 1995 . No significant correlation was detected in analyses involving the calculated parameters $v_{95}$ and $t_{2}$ for the two diseases, suggesting that there was no interaction between them.

\section{Anthracnose curve parameters}

Treatment effects on disease progress rates for anthracnose were inconsistent between the 2 years in which anthracnose was observed. In 1994 (Table 1), neither planting date nor cultivar affected the rate of disease increase, $\beta$. Significant differences $(P<0 \cdot 01)$ in the absolute rate of disease progress, $\theta$ were caused by differences between cultivars $(P<0 \cdot 01)$ in the estimates of final disease severity denoted by the upper asymptote, $\gamma$. In 1995 (Table 2), the first 10-day delay in planting between planting dates 1 and 2 increased the rate of disease progress (both $\beta$ and $\theta, P<0.05$ ), but the subsequent delay between planting dates 2 and 3 reduced it. Interactions between cultivar and planting date in 1995 indicated that while the delay between planting dates 2 and 3 affected rates of disease progress more for the susceptible cultivar KARI Mtama 1 and the moderately resistant cultivar IS 18758, it was the delay between planting dates 1 and 2 that had a greater effect on anthracnose progress on the resistant cultivar IS 8193.

The estimates of time of anthracnose onset $\left(t_{2}\right.$ and $\left.\mu\right)$ were affected by both planting date and cultivar. For all three cultivars, delaying planting by 20 days (i.e. the difference between planting dates 1 and 3 ) decreased time to when disease was first observed $\left(t_{2}\right)$ by 14 days in 

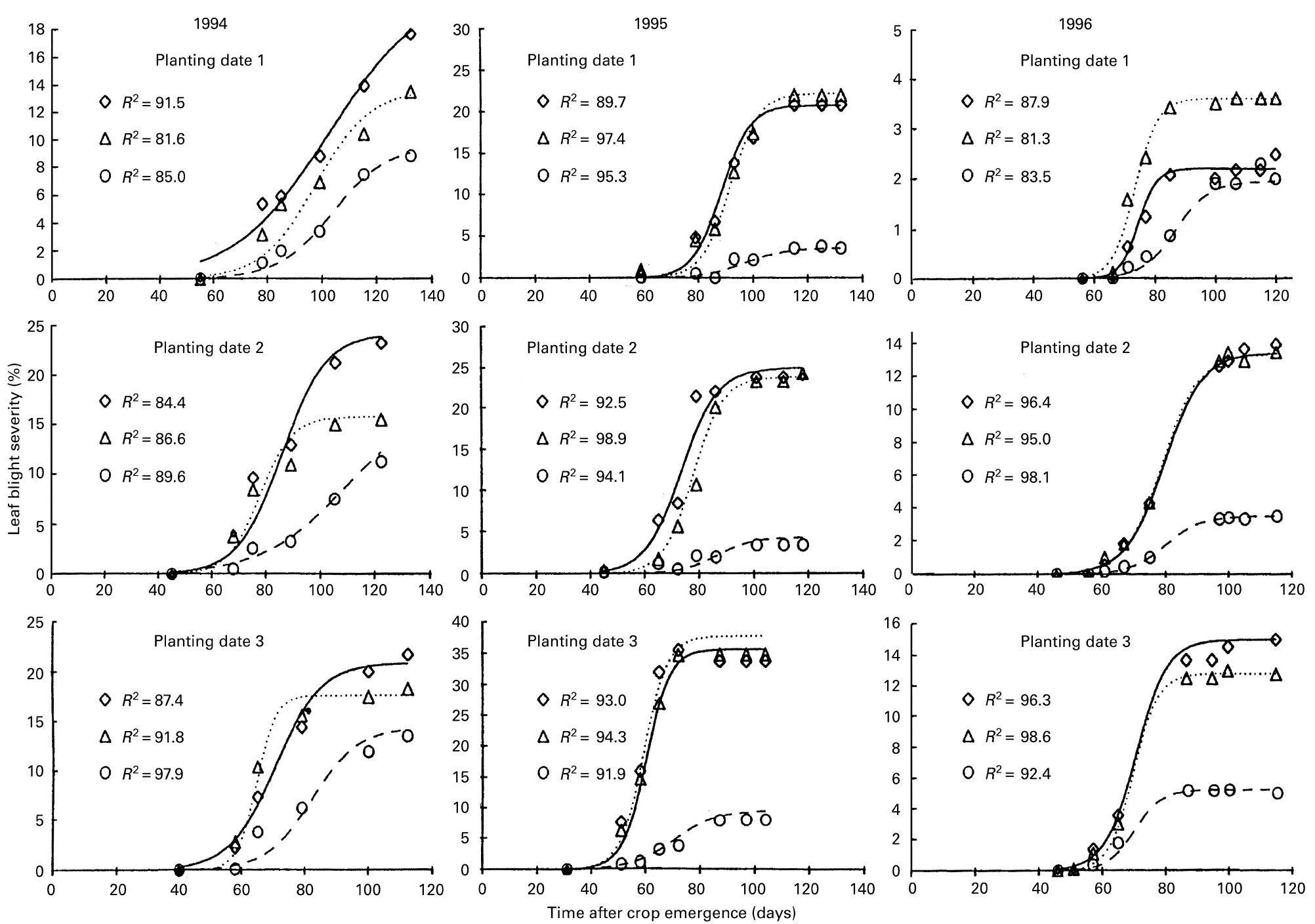

Figure 2 Exserohilum turcicum disease progress on three sorghum cultivars planted at three dates at 10-day intervals from 25 August, 9 March and 21 March in 1994, 1995 and 1996, respectively, at Alupe: $\diamond$ KARI Mtama 1, $\triangle$ IS 18758, O IS 8193. Points represent means of four replicates, smooth lines are the fitted curves, $R^{2}$ values indicate the percentage variance accounted for by the logistic regression. 
Table 1 Mean parameter estimates for anthracnose (C. sublineolum) disease progress curves derived from three planting dates of three sorghum cultivars at Alupe 1994 short rains season

\begin{tabular}{|c|c|c|c|c|c|}
\hline Planting date & Parameter & KARI Mtama 1 & IS 18758 & IS 8193 & Planting date mean \\
\hline \multirow[t]{6}{*}{1} & $\beta\left(\right.$ day $\left.^{-1}\right)$ & $0 \cdot 105$ & $0 \cdot 170$ & $0 \cdot 124$ & 0.133 \\
\hline & $\mu$ (days) & $107 \cdot 1$ & $108 \cdot 3$ & $112 \cdot 6$ & $109 \cdot 3$ \\
\hline & $\gamma(\%)$ & $28 \cdot 0$ & $25 \cdot 2$ & 21.4 & 24.9 \\
\hline & $v_{95}(\%)$ & $6 \cdot 3$ & $2 \cdot 8$ & $2 \cdot 5$ & $3 \cdot 9$ \\
\hline & $t_{2}$ (days) & $79 \cdot 8$ & $93 \cdot 4$ & $93 \cdot 3$ & $88 \cdot 8$ \\
\hline & $\theta(\beta \times \gamma)$ & $2 \cdot 97$ & $4 \cdot 24$ & $2 \cdot 49$ & $3 \cdot 23$ \\
\hline \multirow[t]{6}{*}{2} & $\beta\left(\right.$ day $\left.^{-1}\right)$ & $0 \cdot 106$ & 0.312 & 0.257 & 0.225 \\
\hline & $\mu$ (days) & $102 \cdot 1$ & $93 \cdot 3$ & $98 \cdot 4$ & $97 \cdot 9$ \\
\hline & $\gamma(\%)$ & $29 \cdot 2$ & $18 \cdot 3$ & $16 \cdot 3$ & $21 \cdot 3$ \\
\hline & $v_{95}(\%)$ & $12 \cdot 0$ & $8 \cdot 7$ & $7 \cdot 0$ & $9 \cdot 2$ \\
\hline & $t_{2}$ (days) & $70 \cdot 7$ & $82 \cdot 0$ & $82 \cdot 6$ & 78.5 \\
\hline & $\theta(\beta \times \gamma)$ & 3.02 & $5 \cdot 11$ & $3 \cdot 12$ & $3 \cdot 75$ \\
\hline \multirow[t]{6}{*}{3} & $\beta\left(\right.$ day $\left.^{-1}\right)$ & 0.379 & 0.391 & 0.392 & 0.387 \\
\hline & $\mu$ (days) & $91 \cdot 0$ & $88 \cdot 6$ & $87 \cdot 3$ & $89 \cdot 0$ \\
\hline & $\gamma(\%)$ & $35 \cdot 4$ & $21 \cdot 6$ & $10 \cdot 2$ & $22 \cdot 4$ \\
\hline & $v_{95}(\%)$ & $19 \cdot 7$ & $15 \cdot 2$ & $7 \cdot 7$ & $14 \cdot 2$ \\
\hline & $t_{2}$ (days) & $68 \cdot 2$ & $74 \cdot 2$ & $80 \cdot 8$ & $74 \cdot 4$ \\
\hline & $\theta(\beta \times \gamma)$ & $9 \cdot 35$ & $7 \cdot 03$ & $3 \cdot 68$ & $6 \cdot 69$ \\
\hline \multirow[t]{6}{*}{ Cultivar mean } & $\beta\left(\right.$ day $\left.^{-1}\right)$ & 0.196 & 0.291 & 0.257 & \\
\hline & $\mu$ (days) & $100 \cdot 1$ & $96 \cdot 7$ & 99.5 & \\
\hline & $\gamma(\%)$ & $30 \cdot 9$ & $21 \cdot 7$ & $16 \cdot 0$ & \\
\hline & $v_{95}(\%)$ & $12 \cdot 7$ & 8.9 & $5 \cdot 7$ & \\
\hline & $t_{2}$ (days) & $72 \cdot 9$ & $83 \cdot 2$ & $85 \cdot 6$ & \\
\hline & $\theta(\beta \times \gamma)$ & $5 \cdot 11$ & $5 \cdot 46$ & $3 \cdot 10$ & \\
\hline
\end{tabular}

SEDs: NS = analysis of variance indicated no significant differences between means, $P<0.05$.

$\begin{array}{lllllll} & \beta & \mu & \gamma & v_{95} & t_{2} & \theta \\ \text { Planting dates }(6 \text { d.f.) } & \text { NS } & 4.49 & \text { NS } & 1.81 & \text { NS } & \text { NS } \\ \text { Cultivars }(15 \text { d.f.) } & \text { NS } & \text { NS } & 3.37 & 1.43 & 2.89 & 0.062 \\ \text { Cultivars within planting date }(15 \text { d.f.) } & \text { NS } & \text { NS } & \text { NS } & \text { NS } & \text { NS } & \text { NS }\end{array}$

1994 (Table 1) and by 19 days in 1995 (Table 2). Significant differences in estimates of $t_{2}$ were also observed between cultivars in both 1994 and 1995 . For the resistant cultivar IS 8193, 2\% anthracnose severity $\left(t_{2}\right)$ was estimated to develop after 86 (Table 1 ) and 85 days (Table 2) in 1994 and 1995, respectively. In contrast, for the susceptible cultivar KARI Mtama 1, $t_{2}$ was reached after 73 (Table 1 ) and 78 days (Table 2) after crop emergence in 1994 and 1995, respectively. The average reduction in $\mu$ for a 10 -day delay in planting was 11 days in 1994 (Table 1) and 4 days in 1995 (Table 2), with the interval between planting dates 1 and 2 causing greater reductions than the interval between planting dates 2 and 3 in both years. Between cultivars, $\mu$ differed significantly $(P<0 \cdot 01)$ in both 1994 and 1995, but interactions between planting date and cultivar were not significant.

The 20-day delay in planting between planting dates 1 and 3 resulted in $10 \cdot 3 \%$ (Table 1 ) and $13 \cdot 2 \%$ (Table 2 ) more anthracnose at milk stage $\left(v_{95}\right)$ in 1994 and 1995, respectively. Significant planting date-cultivar interactions $(P<0.01$ in both years $)$ indicated that the effect of delay in planting time was cultivar-dependent. Thus while the 10-day interval between planting dates 1 and 2 increased disease severity at milk stage more in the resistant cultivar IS 8193, the interval between planting dates 2 and 3 had a greater effect for the susceptible cultivar KARI Mtama 1.

\section{Leaf blight curve parameters}

The effects of planting date and cultivar on leaf blight progress rates also varied over the 3 years of the study. In 1994, neither planting date nor cultivar affected rate, $\beta$ or absolute rate, $\theta$ (Table 3). In 1995 and 1996, mean estimates of $\theta$ for the three planting dates indicated an increase in the absolute rate of leaf blight progress with delay in planting (Tables 4 and 5). There were highly significant differences among cultivars $(P<0 \cdot 01)$ in $\theta$ in both 1995 and 1996, with the resistant cultivar IS 8193 having the lowest values in both years. A significant cultivar $\times$ planting date interaction was observed only in the 1995 experiment (Table 4). In that year, the delay between planting dates 2 and 3 increased the absolute rate of leaf blight progress on the susceptible cultivar IS 18758 more than the delay between planting dates 1 and 2. As with anthracnose, a delay in planting significantly reduced the curve-inflection parameter $\mu$ in 
Table 2 Mean parameter estimates for anthracnose (C. sublineolum) disease progress curves derived from three planting dates of three sorghum cultivars at Alupe 1995 long rains season

\begin{tabular}{|c|c|c|c|c|c|}
\hline Planting date & Parameter & KARI Mtama 1 & IS 18758 & IS 8193 & Planting date mean \\
\hline \multirow[t]{6}{*}{1} & $\beta\left(\right.$ day $\left.^{-1}\right)$ & 0.190 & 0.322 & 0.151 & 0.221 \\
\hline & $\mu$ (days) & $101 \cdot 2$ & $104 \cdot 9$ & $120 \cdot 2$ & $108 \cdot 8$ \\
\hline & $\gamma(\%)$ & $70 \cdot 0$ & $42 \cdot 9$ & 68.9 & $60 \cdot 6$ \\
\hline & $v_{95}(\%)$ & $17 \cdot 4$ & $2 \cdot 1$ & $1 \cdot 7$ & $7 \cdot 1$ \\
\hline & $t_{2}$ (days) & $80 \cdot 6$ & $95 \cdot 1$ & $96 \cdot 5$ & $90 \cdot 7$ \\
\hline & $\theta(\beta \times \gamma)$ & $13 \cdot 37$ & $13 \cdot 87$ & $10 \cdot 28$ & $12 \cdot 5$ \\
\hline \multirow[t]{6}{*}{2} & $\beta\left(\right.$ day $\left.^{-1}\right)$ & 0.310 & 0.673 & 0.125 & 0.369 \\
\hline & $\mu$ (days) & $100 \cdot 6$ & $102 \cdot 1$ & $108 \cdot 4$ & $103 \cdot 7$ \\
\hline & $\gamma(\%)$ & $67 \cdot 4$ & $44 \cdot 1$ & $47 \cdot 0$ & $52 \cdot 8$ \\
\hline & $v_{95}(\%)$ & $14 \cdot 1$ & $2 \cdot 3$ & $9 \cdot 3$ & $8 \cdot 8$ \\
\hline & $t_{2}$ (days) & $84 \cdot 6$ & $94 \cdot 3$ & $82 \cdot 7$ & $87 \cdot 2$ \\
\hline & $\theta(\beta \times \gamma)$ & $20 \cdot 56$ & $29 \cdot 68$ & $6 \cdot 41$ & $18 \cdot 06$ \\
\hline \multirow[t]{6}{*}{3} & $\beta\left(\right.$ day $\left.^{-1}\right)$ & $0 \cdot 140$ & $0 \cdot 112$ & $0 \cdot 134$ & 0.129 \\
\hline & $\mu$ (days) & $96 \cdot 1$ & $104 \cdot 3$ & $100 \cdot 3$ & $100 \cdot 2$ \\
\hline & $\gamma(\%)$ & $60 \cdot 9$ & $50 \cdot 4$ & $45 \cdot 0$ & $52 \cdot 1$ \\
\hline & $v_{95}(\%)$ & $28 \cdot 3$ & $17 \cdot 4$ & $15 \cdot 2$ & $20 \cdot 3$ \\
\hline & $t_{2}$ (days) & $68 \cdot 2$ & $71 \cdot 2$ & $75 \cdot 7$ & $71 \cdot 7$ \\
\hline & $\theta(\beta \times \gamma)$ & 8.05 & $5 \cdot 84$ & $5 \cdot 61$ & $6 \cdot 27$ \\
\hline \multirow[t]{6}{*}{ Cultivar mean } & $\beta\left(\right.$ day $\left.^{-1}\right)$ & $0 \cdot 213$ & 0.369 & $0 \cdot 136$ & \\
\hline & $\mu$ (days) & $99 \cdot 3$ & $103 \cdot 8$ & $109 \cdot 8$ & \\
\hline & $\gamma(\%)$ & $66 \cdot 1$ & $45 \cdot 8$ & $53 \cdot 6$ & \\
\hline & $v_{95}(\%)$ & $19 \cdot 9$ & $7 \cdot 5$ & 8.75 & \\
\hline & $t_{2}$ (days) & $77 \cdot 8$ & $86 \cdot 9$ & $85 \cdot 0$ & \\
\hline & $\theta(\beta \times \gamma)$ & $14 \cdot 08$ & $16 \cdot 46$ & 7.92 & \\
\hline
\end{tabular}

SEDs: NS = analysis of variance indicated no significant differences between mans, $P<0.05$.

$\begin{array}{lllllll} & \beta & \mu & \gamma & v_{95} & t_{2} & \theta \\ \text { Planting dates (6 d.f.) } & 0.047 & 1.66 & 2.34 & 2.49 & 1.26 & 2.99 \\ \text { Cultivars (15 d.f.) } & 0.044 & 2.12 & 6.44 & 2.18 & 2.73 & 2.61 \\ \text { Planting dates within cultivar (8 d.f.) } & 0.077 & 3.42 & \text { NS } & \text { NS } & \text { NS } & 4.76 \\ \text { Cultivars within planting dates (15 d.f.) } & 0.078 & 3.67 & \text { NS } & \text { NS } & \text { NS } & 4.53\end{array}$

all 3 years, indicating earlier disease onset in the later sown crop. In 1996, a higher $\mu$ value was recorded for planting date 2 than for planting date 1 , but this was associated with the much higher upper asymptote for planting date 2 (Table 5).

Delay in planting consistently increased estimates of leaf blight severity 95 days after crop emergence $\left(v_{95}\right)$ in all years. A 20-day delay (i.e. that between planting dates 1 and 3 ) increased $v_{95}$ by $9 \cdot 0,18.6$ and $8.4 \%$ in 1994, 1995 and 1996, respectively (Tables 3-5). However, the interaction effects between planting date and cultivar on $v_{95}$ for leaf blight were different from those for anthracnose. For the resistant cultivar IS 8193, increases in leaf blight severity 95 days after crop emergence were greater when caused by the delay between planting dates 2 and 3 than when caused by the delay between planting dates 1 and 2. Conversely, for the susceptible cultivar KARI Mtama 1 the delay between planting dates 2 and 3 had less effect on $v_{95}$, while effects of delay in planting varied between years for IS 18758.

Estimates of the final leaf blight severity denoted by the upper asymptote, $\gamma$ were consistently affected by cultivar in all years. A delay in planting increased final leaf blight at crop maturity in 1995 and 1996 but not in 1994. Significant planting date-cultivar interactions indicated that, in both 1995 and 1996, $\gamma$ for the resistant cultivar IS 8193 was affected more by the delay between planting dates 2 and 3 than between planting dates 1 and 2 . In all 3 years, delaying planting significantly reduced $(P<0 \cdot 01)$ the estimate of time to $2 \%$ leaf blight severity, $t_{2}$, indicating that leaf blight was observed earlier in later-planted crops. There were consistent differences in estimates of $t_{2}$ among cultivars. Higher $t_{2}$ values were estimated for the resistant IS 8193 than for the susceptible cultivars in all 3 years. When $t_{2}$ values exceeded time to $50 \%$ flowering, there was reduced leaf blight severity, irrespective of the level of resistance of the cultivar.

\section{Discussion}

The dynamics of temporal development of sorghum anthracnose and leaf blight were analysed using statistical models to determine the parameters that best describe disease progress in C. sublineolum-sorghum and E. turcicum-sorghum pathosystems, under the effects of different treatments. Use of the logistic 
Table 3 Mean parameter estimates for leaf blight (E. turcicum) disease progress curves derived from three planting dates of three sorghum cultivars at Alupe 1994 short rains season

\begin{tabular}{|c|c|c|c|c|c|}
\hline Planting date & Parameter & KARI Mtama 1 & IS 18758 & IS 8193 & Planting date mean \\
\hline \multirow[t]{6}{*}{1} & $\beta\left(\right.$ day $\left.^{-1}\right)$ & 0.059 & $0 \cdot 152$ & $0 \cdot 101$ & 0.104 \\
\hline & $\mu$ (days) & $102 \cdot 1$ & $97 \cdot 7$ & $109 \cdot 8$ & $103 \cdot 2$ \\
\hline & $\gamma(\%)$ & $21 \cdot 0$ & $16 \cdot 7$ & $13 \cdot 6$ & $17 \cdot 1$ \\
\hline & $v_{95}(\%)$ & $8 \cdot 3$ & $7 \cdot 3$ & $4 \cdot 0$ & $6 \cdot 5$ \\
\hline & $t_{2}$ (days) & $62 \cdot 9$ & $67 \cdot 0$ & $85 \cdot 2$ & $71 \cdot 7$ \\
\hline & $\theta(\beta \times \gamma)$ & 1.23 & 1.61 & $1 \cdot 12$ & 1.32 \\
\hline \multirow[t]{6}{*}{2} & $\beta\left(\right.$ day $\left.^{-1}\right)$ & 0.135 & 0.172 & 0.066 & 0.124 \\
\hline & $\mu$ (days) & $88 \cdot 9$ & $77 \cdot 7$ & $109 \cdot 3$ & $92 \cdot 0$ \\
\hline & $\gamma(\%)$ & $26 \cdot 3$ & $15 \cdot 8$ & $17 \cdot 6$ & $19 \cdot 9$ \\
\hline & $v_{95}(\%)$ & $16 \cdot 0$ & $12 \cdot 6$ & $4 \cdot 7$ & $11 \cdot 1$ \\
\hline & $t_{2}$ (days) & $60 \cdot 2$ & $61 \cdot 0$ & $78 \cdot 1$ & $66 \cdot 1$ \\
\hline & $\theta(\beta \times \gamma)$ & $3 \cdot 20$ & $2 \cdot 44$ & $1 \cdot 13$ & $2 \cdot 25$ \\
\hline \multirow[t]{6}{*}{3} & $\beta\left(\right.$ day $\left.^{-1}\right)$ & 0.282 & 0.327 & $0 \cdot 140$ & 0.250 \\
\hline & $\mu$ (days) & $70 \cdot 7$ & $64 \cdot 7$ & $82 \cdot 4$ & $72 \cdot 6$ \\
\hline & $\gamma(\%)$ & $21 \cdot 2$ & $17 \cdot 6$ & $14 \cdot 4$ & $17 \cdot 7$ \\
\hline & $v_{95}(\%)$ & $18 \cdot 7$ & $17 \cdot 4$ & $10 \cdot 4$ & $15 \cdot 5$ \\
\hline & $t_{2}$ (days) & $53 \cdot 6$ & $56 \cdot 6$ & $66 \cdot 5$ & $58 \cdot 5$ \\
\hline & $\theta(\beta \times \gamma)$ & $6 \cdot 14$ & $5 \cdot 57$ & $2 \cdot 0$ & $4 \cdot 57$ \\
\hline \multirow[t]{6}{*}{ Cultivar mean } & $\beta\left(\right.$ day $\left.^{-1}\right)$ & 0.159 & 0.217 & 0.102 & \\
\hline & $\mu$ (days) & $87 \cdot 2$ & $80 \cdot 0$ & $100 \cdot 5$ & \\
\hline & $\gamma(\%)$ & $22 \cdot 8$ & $16 \cdot 7$ & $15 \cdot 2$ & \\
\hline & $v_{95}(\%)$ & $14 \cdot 4$ & $12 \cdot 4$ & $6 \cdot 3$ & \\
\hline & $t_{2}$ (days) & 58.9 & 61.5 & $76 \cdot 6$ & \\
\hline & $\theta(\beta \times \gamma)$ & 3.52 & $3 \cdot 21$ & 1.42 & \\
\hline
\end{tabular}

SEDs: NS = analysis of variance indicated no significant differences between means, $P<0.05$.

$\begin{array}{lllllll} & \beta & \mu & \gamma & v_{95} & t_{2} & \theta \\ \text { Planting dates }(6 \text { d.f.) } & \text { NS } & 7.85 & \text { NS } & 1.41 & 2.56 & \text { NS } \\ \text { Cultivars (18 d.f.) } & \text { NS } & 4.00 & 1.69 & 1.17 & 2.54 & \text { NS } \\ \text { Cultivars within planting dates (18 d.f.) } & \text { NS } & 6.92 & \text { NS } & \text { NS } & \text { NS } & \text { NS }\end{array}$

model allowed direct comparisons to be drawn between disease epidemics caused by the two pathogens. The absence of a detectable interaction between anthracnose and leaf blight was not surprising. There were clear differences in time of disease onset for the two epidemics and, in most cases, leaf blight severity was low. It was therefore unlikely that the two pathogens were competing for host resources such as green leaf tissues. This conclusion is supported by the pattern of leaf blight progress in the absence of anthracnose in 1996. It was relatively easy to discriminate between anthracnose and leaf blight disease symptoms on the same plant, reducing the likelihood that errors in estimated severity for the two diseases would be correlated (Madden et al., 1987).

There was considerable variation in the rate parameter $\beta$, associated with both planting date and cultivar, but the planting date effects on $\beta$ for different cultivars were not consistent over the years for both $C$. sublineolum and E. turcicum epidemics. In addition, $\beta$ was less sensitive than other parameters to treatments. This observation is in agreement with Gilligan (1990), who reported that logistic rate parameters were often not affected by treatments. Calculating the absolute rate parameter $\theta$ improved treatment comparisons, but only when the differences in $\gamma$ were large (e.g. the leaf blight curves for different cultivars in the 1995 experiment). In treatment comparisons involving nonlinear logistic regressions in which the upper asymptotes differ (as with the cultivar differences evaluated here), placing emphasis on the rate parameter can be potentially misleading. This observation is of particular interest, as in many studies involving logistic regressions the rate parameter $\beta$ has been used for treatment comparisons (Jeger, 1984; Gilligan, 1990; Campbell \& Madden, 1990; Madden \& Campbell, 1990).

The estimate of $t_{2}, v_{95}$ and $\mu$ provided consistent and reliable means for treatment comparisons over the 3 years of the study, for both anthracnose and leaf blight. Estimates of $t_{2}$ were consistent over the years and provided a reliable estimate of the time when disease is first observed in the field. This parameter is therefore recommended as a more realistic estimate of time of disease onset in place of the 'locational' parameter $\mu$ (Gilligan, 1990), which is an estimate of the midpoint in the course of the disease epidemic. The upper asymptote $\gamma$ was useful for comparing both planting date and cultivar effects in leaf blight epidemics, but was less useful for anthracnose where consistent differences were observed only among cultivars. Thus treatment 
Table 4 Mean parameter estimates for leaf blight (E. turcicum) disease progress curves derived from three planting dates of three sorghum cultivars at Alupe 1995 long rains season

\begin{tabular}{|c|c|c|c|c|c|}
\hline Planting date & Parameter & KARI Mtama 1 & IS 18758 & IS 8193 & Planting date mean \\
\hline \multirow[t]{6}{*}{1} & $\beta\left(\right.$ day $\left.^{-1}\right)$ & $0 \cdot 192$ & $0 \cdot 194$ & $0 \cdot 136$ & $0 \cdot 174$ \\
\hline & $\mu$ (days) & $88 \cdot 4$ & $91 \cdot 8$ & $96 \cdot 5$ & $92 \cdot 2$ \\
\hline & $\gamma(\%)$ & $18 \cdot 8$ & $18 \cdot 7$ & 3.5 & $13 \cdot 7$ \\
\hline & $v_{95}(\%)$ & $14 \cdot 6$ & 11.4 & 1.6 & $9 \cdot 2$ \\
\hline & $t_{2}$ (days) & $76 \cdot 9$ & $79 \cdot 2$ & $100 \cdot 3$ & $85 \cdot 5$ \\
\hline & $\theta(\beta \times \gamma)$ & 3.71 & $3 \cdot 18$ & 0.49 & $2 \cdot 46$ \\
\hline \multirow[t]{6}{*}{2} & $\beta\left(\right.$ day $\left.^{-1}\right)$ & $0 \cdot 151$ & 0.182 & 0.116 & $0 \cdot 150$ \\
\hline & $\mu$ (days) & $76 \cdot 7$ & $75 \cdot 9$ & $86 \cdot 3$ & $79 \cdot 6$ \\
\hline & $\gamma(\%)$ & $27 \cdot 9$ & $23 \cdot 8$ & $6 \cdot 3$ & $19 \cdot 3$ \\
\hline & $v_{95}(\%)$ & $26 \cdot 1$ & $23 \cdot 0$ & $4 \cdot 4$ & $17 \cdot 9$ \\
\hline & $t_{2}$ (days) & $59 \cdot 5$ & $62 \cdot 8$ & $81 \cdot 8$ & $68 \cdot 0$ \\
\hline & $\theta(\beta \times \gamma)$ & $4 \cdot 18$ & $4 \cdot 29$ & 0.75 & 3.07 \\
\hline \multirow[t]{6}{*}{3} & $\beta\left(\right.$ day $\left.^{-1}\right)$ & 0.229 & 0.228 & $0 \cdot 136$ & $0 \cdot 198$ \\
\hline & $\mu$ (days) & $60 \cdot 2$ & $60 \cdot 2$ & $70 \cdot 7$ & $63 \cdot 7$ \\
\hline & $\gamma(\%)$ & $35 \cdot 7$ & $37 \cdot 8$ & $10 \cdot 5$ & $28 \cdot 0$ \\
\hline & $v_{95}(\%)$ & $35 \cdot 7$ & $37 \cdot 8$ & 9.85 & $27 \cdot 8$ \\
\hline & $t_{2}$ (days) & $47 \cdot 8$ & $47 \cdot 4$ & $59 \cdot 4$ & 51.5 \\
\hline & $\theta(\beta \times \gamma)$ & $8 \cdot 15$ & $8 \cdot 61$ & $1 \cdot 39$ & $6 \cdot 05$ \\
\hline \multirow[t]{6}{*}{ Cultivar mean } & $\beta\left(\right.$ day $\left.^{-1}\right)$ & 0.192 & 0.213 & 0.130 & \\
\hline & $\mu$ (days) & $75 \cdot 1$ & 75.9 & 84.5 & \\
\hline & $\gamma(\%)$ & $27 \cdot 5$ & $26 \cdot 8$ & $6 \cdot 8$ & \\
\hline & $v_{95}(\%)$ & $25 \cdot 5$ & $24 \cdot 1$ & $5 \cdot 3$ & \\
\hline & $t_{2}$ (days) & 61.4 & $63 \cdot 1$ & $80 \cdot 5$ & \\
\hline & $\theta(\beta \times \gamma)$ & $5 \cdot 35$ & $5 \cdot 36$ & 0.88 & \\
\hline
\end{tabular}

SEDs: NS = analysis of variance indicated no significant differences between means, $P<0.05$.

$\begin{array}{lllllll} & \beta & \mu & \gamma & v_{95} & t_{2} & \theta \\ \text { Planting dates (6 d.f.) } & 0.011 & 0.71 & 1.93 & 1.66 & 1.67 & 0.373 \\ \text { Cultivars (18 d.f.) } & 0.018 & 0.13 & 1.55 & 1.11 & 1.32 & 0.328 \\ \text { Planting dates within cultivar (20 d.f.) } & \text { NS } & \text { NS } & 2.93 & 2.28 & 2.51 & 0.59 \\ \text { Cultivars within planting date (18 d.f.) } & \text { NS } & \text { NS } & 2.69 & 1.91 & 2.29 & 0.569\end{array}$

differences in progress curves for both diseases could be summarized using three parameters: time when disease is first observed, $t_{2}$, disease severity at milk stage, $v_{95}$, and the 'locational' parameter $\mu_{\text {. }}$ Use of the upper asymptote would improve comparisons of leaf blight curves. These results indicate that, in resistance breeding, observations based on time of disease onset and disease severity approximately 3 weeks after plant flowering (milk stage) would provide the best criteria for distinguishing between resistant and susceptible sorghum cultivars for both leaf blight and anthracnose.

In the two seasons when the diseases were observed together, epidemics of leaf blight started earlier than those of anthracnose. Anthracnose epidemics began after anthesis and increased rapidly through the grainfilling stage of crop development. Given that accumulation of grain weight is most rapid soon after sorghum anthesis (Dogget, 1988; Paul, 1990), a more severe impact on yield would be expected from leaf blight epidemics than from anthracnose epidemics. However, the results of the present study indicate that this would not necessarily be the case. Leaf blight ceased to develop after crop flowering, implying that changes in physiological status of the host affected E. turcicum development. As C. sublineolum epidemics always had higher disease levels by the milk stage $\left(v_{95}\right)$ and ended in higher final disease levels at crop senescence, this pathogen would have a more significant effect on grain yield. These results are consistent with changes in resistance/susceptibility to leaf blight and anthracnose that have been observed as sorghum plants approach maturity. Reduction in the rate of leaf blight progress may result from mature plant resistance (Tuleen \& Frederiksen, 1977; Julian et al., 1994), which is thought to be associated with increased concentration of phenolic antimicrobial compounds (Mohan \& Lakshmanan, 1987). An increased susceptibility to anthracnose with plant maturity has been reported in a number of studies on different sorghum cultivars (Ferreira \& Warren, 1982; Jamil \& Nicholson, 1987; Ashok-Mishra et al., 1992; Peacocke, 1995) but the mechanism involved is not well understood.

Resistance to both C. sublineolum and E. turcicum in sorghum is well documented (Frederiksen et al., 1975; Ferreira \& Warren, 1982; Pande et al., 1991; Casela et al., 1993). However, with the exception of Thomas et al. (1996) and Peacocke (1995), few studies have examined how host resistance affects the dynamics of 
Table 5 Mean parameter estimates for leaf blight (E. turcicum) disease progress curves derived from three planting dates of three sorghum cultivars at Alupe 1996 long rains season

\begin{tabular}{|c|c|c|c|c|c|}
\hline Planting date & Parameter & KARI Mtama 1 & IS 18758 & IS 8183 & Planting date mean \\
\hline \multirow[t]{6}{*}{1} & $\beta\left(\right.$ day $\left.^{-1}\right)$ & 0.327 & 0.267 & 0.539 & 0.377 \\
\hline & $\mu$ (days) & 74.5 & $73 \cdot 4$ & $75 \cdot 4$ & 74.5 \\
\hline & $\gamma(\%)$ & $2 \cdot 2$ & $3 \cdot 6$ & 0.98 & 1.95 \\
\hline & $v_{95}(\%)$ & $2 \cdot 2$ & 3.6 & 0.96 & $2 \cdot 2$ \\
\hline & $t_{2}$ (days) & $80 \cdot 5$ & $75 \cdot 8$ & $82 \cdot 7$ & $88 \cdot 8$ \\
\hline & $\theta(\beta \times \gamma)$ & 0.72 & 0.96 & 0.53 & 0.74 \\
\hline \multirow[t]{6}{*}{2} & $\beta\left(\right.$ day $\left.^{-1}\right)$ & 0.165 & 0.172 & $0 \cdot 178$ & 0.172 \\
\hline & $\mu$ (days) & $79 \cdot 8$ & $79 \cdot 0$ & $80 \cdot 0$ & $79 \cdot 5$ \\
\hline & $\gamma(\%)$ & $13 \cdot 5$ & $13 \cdot 4$ & 3.5 & $10 \cdot 1$ \\
\hline & $v_{95}(\%)$ & $9 \cdot 5$ & $12 \cdot 5$ & $3 \cdot 2$ & $8 \cdot 4$ \\
\hline & $t_{2}$ (days) & $68 \cdot 8$ & $69 \cdot 0$ & $81 \cdot 8$ & $73 \cdot 2$ \\
\hline & $\theta(\beta \times \gamma)$ & $2 \cdot 23$ & $2 \cdot 31$ & 0.62 & $1 \cdot 72$ \\
\hline \multirow[t]{6}{*}{3} & $\beta\left(\right.$ day $\left.^{-1}\right)$ & 0.201 & 0.257 & 0.239 & 0.232 \\
\hline & $\mu$ (days) & $70 \cdot 7$ & $70 \cdot 0$ & $70 \cdot 3$ & $70 \cdot 1$ \\
\hline & $\gamma(\%)$ & $14 \cdot 0$ & $12 \cdot 8$ & $5 \cdot 4$ & $10 \cdot 7$ \\
\hline & $v_{95}(\%)$ & $13 \cdot 9$ & $12 \cdot 7$ & $5 \cdot 2$ & $10 \cdot 6$ \\
\hline & $t_{2}$ (days) & $61 \cdot 3$ & $62 \cdot 3$ & $68 \cdot 6$ & $64 \cdot 1$ \\
\hline & $\theta(\beta \times \gamma)$ & $2 \cdot 81$ & $3 \cdot 29$ & $1 \cdot 29$ & $2 \cdot 46$ \\
\hline \multirow[t]{6}{*}{ Cultivar mean } & $\beta\left(\right.$ day $\left.^{-1}\right)$ & 0.243 & 0.231 & 0.319 & \\
\hline & $\mu$ (days) & 74.9 & $74 \cdot 1$ & $75 \cdot 4$ & \\
\hline & $\gamma(\%)$ & 11.4 & 9.60 & $3 \cdot 2$ & \\
\hline & $v_{95}(\%)$ & 9.5 & $9 \cdot 6$ & $3 \cdot 1$ & \\
\hline & $t_{2}$ (days) & $70 \cdot 2$ & $69 \cdot 0$ & $79 \cdot 5$ & \\
\hline & $\theta(\beta \times \gamma)$ & 1.92 & $2 \cdot 19$ & 0.81 & \\
\hline
\end{tabular}

SEDs: NS = analysis of variance indicated no significant differences between means, $P<0.05$.

$\begin{array}{lllllll} & \beta & \mu & \gamma & v_{95} & t_{2} & \theta \\ \text { Planting dates (6 d.f.) } & 0.064 & 1.30 & 0.36 & 0.37 & 2.40 & 0.058 \\ \text { Cultivars (18 d.f.) } & \text { NS } & \text { NS } & 0.66 & 0.61 & 1.06 & \text { NS } \\ \text { Planting date within cultivar (20 d.f.) } & \text { NS } & \text { NS } & 0.99 & 0.93 & \text { NS } & 0.446 \\ \text { Cultivars within planting dates (18 d.f.) } & \text { NS } & \text { NS } & 1.14 & 1.05 & \text { NS } & \text { NS }\end{array}$

disease progress in sorghum. In the present study, host resistance was consistently associated with delayed onset of the two diseases, as measured by $t_{2}$ and the locational parameter $\mu$, with lower rates of progress and with reduced disease severity at crop maturity. In polycyclic diseases such as those considered in this study, delayed disease onset could indicate longer latent periods of the pathogens in resistant cultivars, while reduced rate of progress and lower disease levels may indicate inhibition of pathogen development or host colonization.

The earlier disease onset associated with delayed planting for both anthracnose and leaf blight is thought to be due to increased inoculum from infected plants in adjacent plots. Plants from the third planting date, i.e. a 20-day delay in planting, were therefore expected to develop the highest disease severity, particularly for leaf blight as this is more severe on younger plants (Tuleen \& Frederiksen, 1977; Julian et al., 1994). That this was not always the case suggests that additional factors may also be important in disease development. The presence of significant interactions between planting date and cultivar on parameter estimates for both anthracnose and leaf blight indicates the effects of environment on disease progress. Although large amounts of inoculum may be essential for early disease onset, climatic conditions, for example dry weather, could also profoundly affect disease progress. The results presented in this study illustrate that planting date should be a critical consideration in developing screening programmes for resistance to foliar diseases in sorghum. It is therefore proposed that, when screening for resistance to both anthracnose and leaf blight, test entries should be planted at least 15 days later than the normal planting time, usually defined by the onset of seasonal rains in eastern Africa.

\section{Acknowledgements}

We thank the Kenya Agricultural Research Institute (KARI) for kindly hosting our field experiments, and John Were, Eric Manyasa, Absalom Ilah and Humphrey Emojong for their technical support at Alupe. We would also like to thank Johnson Holt (NRI) and Richard Coe (ICRAF) for their advice with the statistical analysis. This paper is an output from a project jointly funded by the UK Department for International Development (DFID) and the International Crops Research Institute for the Semi-Arid Tropics (ICRISAT). The views 
expressed are those of the authors and not necessarily those of DFID or ICRISAT.

\section{References}

Ashok-Mishra, Siradhana BS, Mishra A, 1992. Effect of host age on sorghum anthracnose. Gujarat Agricultural University Research Journal 18, 135-6.

Basu Chaudhary KC, Mathur SB, 1979. Infection of sorghum seeds by Colletotrichum graminicola. 1. Survey, location in seed and transmission of the pathogen. Seed Science and Technology 7, 87-92.

Benedict WG, 1979. Influence of photoperiod on sporulation and infection by Helminthosporium turcicum on Zea mays. Canadian Journal of Botany 57, 1809-14.

Berger RD, 1970. Forecasting Helminthosporium turcicum attacks in Florida sweet corn. Phytopathology 60, 1284.

Bergquist R, 1986. Leaf blight. In: Frederiksen RA, ed. Compendium of Sorghum Diseases. St Paul, Minnesota, USA: American Phytopathological Society, 9-10.

Campbell CL, Madden LV, 1990. Introduction to Plant Disease Epidemiology. New York, USA: John Wiley.

Cardwell KF, 1989. Pathotypes of Colletotrichum graminicola and seed transmission of sorghum anthracnose. Plant Disease 73, 255-7.

Casela CR, Frederiksen RA, 1993. Survival of Colletotrichum graminicola sclerotia in sorghum stalk residues. Plant Disease 77, 825-7.

Casela CR, Frederiksen RA, Ferreira AS, 1993. Evidence for dilatory resistance to anthracnose in sorghum. Plant Disease 77, 908-11.

Dogget H, 1988. Sorghum, 2nd edn. Harlow, UK: Longman.

FAO, 1997. Quartlerly Statistics, 10. Rome: Food and Agriculture Organization of the UN.

Ferreira AS, Warren HL, 1982. Resistance of sorghum to Colletotrichum graminicola. Plant Disease 66, 773-5.

Frederiksen RA, ed., 1986. Compendium of Sorghum Diseases. St Paul, Minnesota, USA: American Phytopathological Society.

Frederiksen RA, Rosenow DT, Tuleen DM, 1975. Resistance to Exserohilum turcicum in sorghum. Plant Disease Reporter 59, 547-8.

Genstat 5, 1993. Release 32 Reference Manual. Oxford, UK: Clarendon Press.

Gilligan CA, 1990. Comparison of disease progress curves. New Phytologist 115, 223-42.

Harris HB, Johnson BJ, Dobson JW, Luttrel ES, 1964. Evaluation of anthracnose on grain sorghum. Crop Science 4, 460-2.

Hennessy GG, de Milliano WAJ, McLaren CG, 1990. Influence of primary weather variables on sorghum leaf blight severity in Southern Africa. Phytopathology 80, 943-5.

Hulluka M, Esele JPE, 1992. Sorghum diseases in eastern Africa. In: de Milliano WJA, Frederiksen RA, Bergston GD, eds. Sorghum and Millet Diseases: A Second World Review. Patancheru, India: ICRISAT, 21-4.

Jaetzold R, Schmidt H, 1982. Farm Management Handbook of Kenya. Nairobi, Kenya: Ministry of Agriculture, Kenya and GTZ.
Jamil FF, Nicholson RL, 1987. Susceptibility of corn to isolates of Colletotrichum graminicola pathogenic to other grasses. Plant Disease 71, 809-10.

Jeger MJ, 1984. Relation between the rate parameters and latent and infectious periods during plant disease epidemics. Phytopathology 74, 1148-52.

Julian AM, de Milliano WAJ, 1992. Development of Exserobilum turcicum (northern leaf blight) on sorghum in Zimbabwe. Sorghum Newsletter 35, 27-8.

Julian AM, Crowson HL, de Milliano WJ, 1994. Factors influencing epidemiology of Exserohilum turcicum on sorghum. African Crop Science, Conference proceedings 1, 263-8.

King SB, Mukuru SZ, 1994. An overview of sorghum finger millet and pearl millet in eastern Africa with special attention to diseases. In: Danial DL, ed. Breeding for Disease Resistance with Emphasis on Durability. Wageningen, Netherlands: Wageningen Agricultural University, 24-34.

Levy Y, 1984. Overwintering of Exserohilum turcicum in Israel. Phytoparasitica 12, 177-82.

Levy Y, 1991. Variation in fitness among field isolates of Exserohilum turcicum in Israel. Plant Disease 75, 163-6.

Madden LV, 1986. Statistical analysis and comparison of disease progress curves. In: Leonard KJ, Fry WE, eds. Plant Disease Epidemiology, Vol 1: Population Dynamics and Management. New York, USA: Macmillan, 55-84.

Madden LV, Campbell CL, 1990. Nonlinear disease progress curves. In: Kranz J, ed. Epidemics of Plant Disease, 2nd edn. Berlin, Germany: Springer-Verlag, 96-126.

Madden LV, Pirone TP, Raccah B, 1987. Temporal analysis of two viruses increasing in the same tobacco fields. Phytopathology 77, 974-80.

Mead R, Curnow RJ, Hasted AM, 1993. Statistical Methods in Agriculture and Experimental Biology, 2nd edn. London, UK: Chapman \& Hall.

Meredith DS, 1965. Violent spore release in Helminthosporium turcicum in Nebraska. Phytopathology 55, 1099-102.

Mohan S, Lakshmanan P, 1987. Studies on the biochemical changes in Sorghum bicolor due to leaf blight disease and tridemorph application. Madras Agricultural Journal 74, 430-3.

Mukuru SZ, 1993. Sorghum and millets in Eastern Africa. In: Byth DE, ed. Sorghum and Millets Commodities and Research Environment. Patancheru, India: ICRISAT, $55-62$.

Nicholson RL, Moraes WBC, 1980. Survival of Colletotrichum graminicola: importance of the spore matrix. Phytopathology 70, 255-61.

Nobel M, Richardson MJ, 1968. Annotated list of seed-borne diseases. Proceedings of International Seed Testing Association No. 33. Zurich, Switzerland: ISTA.

Pande S, Mughogho LK, Badhiopadhyay R, Karunakar RI, 1991. Variation in pathogenicity and cultural characteristics of sorghum isolates of Colletotrichum graminicola in India. Plant Disease 75, 778-83.

Paul CL, 1990. Sorghum Physiology. Patancheru, India: ICRISAT.

Peacocke BJ, 1995. Epidemiology and Management of Anthracnose from Sorghum. Reading, UK: University of Reading, PhD Thesis. 
Powell P, Ellis M, Alaeda M, Sotomayer AM, 1977. Effect of natural anthracnose epiphytotic on yield, grain quality, seed health and seed borne fungi in Sorghum bicolor. Sorghum Newsletter 20, 77-8.

Rouse DI, 1985. Construction of temporal models. I. Disease progress of air-borne pathogens. In: Gilligan CA, ed. Advances in Plant Pathology, Vol. 3: Mathematical Modelling of Crop Disease. London, UK: Academic Press, 11-29.

Rutto JK, 1982. The status of sorghum improvement in Kenya. In: Gebrekdan B, ed. Proceedings of the Regional Workshop on Sorghum Improvement in Eastern Africa, 1982. Nairobi, Kenya: EARCAL (Eastern Africa Regional Cereals and Legumes).

Saari EE, Prescott JM, 1975. A scale for appraising the foliar intensity of wheat diseases. Plant Disease Reporter 59, $377-80$.
Sutton BC, 1980. The Coelomycetes. Kew, UK: Commonwealth Mycological Institute.

Tarr SAJ, 1962. Diseases of Sorghum, Sudan grass and Broom Corn. Kew, UK: Commonwealth Mycological Institute.

Thomas MD, Sissoko I, Sacco M, 1996. Development of leaf anthracnose and its effect on yield and grain weight of sorghum in West Africa. Plant Disease 80, 151-3.

Tomerlin JR, Howell A, 1988. DISTRAIN. A computer program for training people to estimate disease severity on cereals. Plant Disease 72, 455-9.

Tuleen DM, Frederiksen RA, 1977. Characteristics of resistance to Exserohilum (Helminthosporium) turcicum in Sorghum bicolor. Plant Disease Reporter 61, 657-61. Vanderplank JE, 1963. Plant Diseases: Epidemics and Control. New York, USA: Academic Press. 